\title{
Identification of the $\sigma^{\mathrm{E}}$ subunit of Escherichia coli RNA polymerase: a second alternate $\sigma$ factor involved in high-temperature gene expression
}

\author{
James W. Erickson and Carol A. Gross \\ Department of Bacteriology, University of Wisconsin, Madison, Wisconsin 53706 USA
}

\begin{abstract}
The rpoH gene of Escherichia coli encodes $\sigma^{32}$, the 32-kD $\sigma$-factor responsible for the heat-inducible transcription of the heat shock genes. $\mathrm{rpoH}$ is transcribed from at least three promoters. Two of these promoters are recognized by RNA polymerase containing $\sigma^{70}$, the predominant $\sigma$-factor. We purified the factor responsible for recognizing the third $r p o H$ promoter $(r p o H$ P3) and identified it as RNA polymerase containing a novel $\sigma$ factor with an apparent $M_{r}$ of 24,000 . This new $\sigma$, which we call $\sigma^{\mathrm{E}}$, is distinct from the known $\sigma$ factors in molecular weight and promoter specificity. $\sigma^{\mathrm{E}}$ holoenzyme will not recognize the $\sigma^{70}$ or $\sigma^{32}$-controlled promoters we tested, but it does transcribe the $h \operatorname{tr} A$ gene, which is required for viability at temperatures $>42^{\circ} \mathrm{C}$. The in vivo role of $\sigma^{\mathrm{E}}$ is not known. The transcripts from the $\sigma^{\mathrm{E}}$-controlled $r p o H \mathrm{P} 3$ and htrA promoters are most abundant at very high temperature, suggesting the $\sigma^{\mathrm{E}}$ holoenzyme may transcribe a second set of heatinducible genes that are involved in growth at high temperature or in thermotolerance.
\end{abstract}

[Key Words: Heat shock; heat inducible; transcription; $\boldsymbol{\sigma}$-factor; rpoH gene]

Received March 23, 1989; revised version accepted June 16, 1989.

When Escherichia coli cells are transferred to temperatures $>40^{\circ} \mathrm{C}$, complex changes in cellular structure, composition, and in the patterns of gene expression occur. The most dramatic change in gene expression is the increased synthesis of the 17 heat shock proteins that is termed the heat shock response (for review, see Neidhardt and VanBogelen 1987). The temperature-regulated expression of the heat shock proteins requires RNA polymerase containing the $\sigma^{32}$-subunit $\left\langle E \sigma^{32}\right\}$ (Neidhardt and VanBogelen 1981; Yamamori and Yura 1982; Grossman et al. 1984; Cowing et al. 1985). Following transfer to a high growth temperature, the amount of $\sigma^{32}$ increases, resulting in increased transcription initiation by $\mathrm{E \sigma}^{32}$ at the heat shock promoters. This nearly 20 -fold increase in $\sigma^{32}$ concentration is shortlived, and by $20-30 \mathrm{~min}$ at the high growth temperature, the amount of $\sigma^{32}$ and thus, the expression of the heat shock genes, declines to three to five times the value at low temperature (Straus et al. 1987). If the temperature to which the cells are shifted is not too high $\left(\leqslant 44^{\circ} \mathrm{C}\right)$, the heat shock response is superimposed over an essentially normal pattern of gene expression, suggesting that the synthesis of most $E$. coli proteins is not affected greatly by such temperature shifts (Herendeen et al. 1979; Neidhardt et al. 1984; Neidhardt and VanBogelen 1987).

The heat shock response is more extreme when cells

'Present address: Department of Biology, Princeton University, Princeton, New Jersey 08544 USA. are shifted to a lethal temperature such as $50^{\circ} \mathrm{C}$. Under these conditions, heat shock proteins account for the major fraction of protein synthesis (Neidhardt et al. 1984; Paek and Walker 1986; VanBogelen et al. 1987a). This extreme response occurs for two reasons: First, the synthesis of most non-heat shock proteins is turned off, probably because the activity of $\sigma^{70}$, the primary $\sigma$ factor, is reduced under these conditions (Erickson et al. 1987; Skelly et al. 1987). Second, the heat shock genes are transcribed at high constitutive rates, and their mRNAs are translated for as long as the cells are able to synthesize protein. The continued synthesis of the heat shock proteins is important for survival at $50^{\circ} \mathrm{C}$ because E. coli mutants that are unable to increase the synthesis of heat shock proteins die much more rapidly than wildtype cells after a shift to $50^{\circ} \mathrm{C}$ /Yamamori and Yura 1982; Neidhardt et al. 1984; J.W. Erickson and C.A. Gross, unpubl.).

Because $\sigma^{32}$ is an unstable molecule $\left(t_{12}=1 \mathrm{~min}\right)$, transcription of the heat shock genes requires continuous synthesis of $\sigma^{32}$ (Straus et al. 1987). Under normal growth conditions, the $r p o H$ gene, which encodes $\sigma^{32}$, is transcribed from three promoters, $\mathrm{P} 1, \mathrm{P} 3$, and $\mathrm{P} 4$; however, only P3 functions following a shift to $50^{\circ} \mathrm{C}$ (Erickson et al. 1987). The promoters $\mathrm{P} 1$ and $\mathrm{P} 4$, which are recognized by RNA polymerase containing $\sigma^{70}\left(\mathrm{E \sigma}^{70}\right)$, are shut off after shift to $50^{\circ} \mathrm{C}$; therefore, at $50^{\circ} \mathrm{C}, \mathrm{\sigma}^{32}$ synthesis depends solely on the transcript originating from rpoH P3.

We investigated the regulation of the rpoH P3 pro- 
moter because of its crucial role in high-temperature physiology. The simplest explanation for the strong transcription from $\mathrm{P} 3$ at $50^{\circ} \mathrm{C}$ was that it is recognized by a novel, heat-stable form of RNA polymerase, as our previous studies suggested that neither $\mathrm{E \sigma}^{70}$ nor $\mathrm{E \sigma}^{32}$ transcribed from this promoter. We could not, however, rule out the possibility that either $\mathrm{E}^{70}$ or $\mathrm{E \sigma}^{32}$, in conjunction with an auxiliary factor, transcribed from гроH P3.

To resolve this issue, we purified the factors required for transcription from rpoH P3. The P3 promoter is recognized by a form of RNA polymerase containing a $\sigma$ subunit with an apparent $M_{r}$ of 24,000 . This $24-\mathrm{kD} \sigma$, which we call $\sigma^{\mathrm{E}}$, is distinct from any known subunit of RNA polymerase and directs core RNA polymerase to initiate transcription from rpoH P3 and from the promoter of the $h \operatorname{tr} A(\operatorname{deg} P)$ gene (Lipinska et al. 1988) that is required for growth and survival only at high temperature (Lipinska et al. 1989). We do not know what other genes are under the control of $\sigma^{\mathrm{E}}$, but the properties of the rpoH P3 and htrA promoters suggest that $\sigma^{\mathrm{E}}$ regulates other genes that are involved in growth at, or in resistance to killing by, high temperatures.

\section{Results}

To identify the factor responsible for transcription from the rpoH P3 promoter, we prepared cell-free extracts that transcribed from $\mathrm{P} 3$ and used those extracts to purify the factor and determine its biochemical function. The extracts were prepared from cells that had been shifted from 30 to $50^{\circ} \mathrm{C}$ for $45 \mathrm{~min}$. These conditions were chosen because $\mathrm{S} 1$ mapping of $r p o H$ mRNA indicated that transcription from $\mathrm{P} 3$ was at a maximum between 30 and $60 \mathrm{~min}$ after a shift to $50^{\circ} \mathrm{C}$, and that $\sigma^{70}$ activity, as judged by transcription from $r p o H ~ P l$ and $\mathrm{P} 4$, was reduced greatly under these conditions (Erickson et al. 1987). This reduction in $\sigma^{70}$ activity was important, because in vitro transcription from the $\sigma^{70}$-controlled P4 promoter could have obscured low-level transcription from the overlapping P3 promoter. To reduce the amount of $\sigma^{70}$ further, most extracts were prepared from cells carrying the rpoD800 mutation, which results in an altered $\sigma^{70}$ that is degraded rapidly at high temperature (Grossman et al. 1983). The experiments described in the following text demonstrate that rpoH P3 is recog. nized by RNA polymerase, which contains a new $\sigma$ factor with an apparent $M_{r}$ of 24,000 .

\section{Transcription from $\mathrm{rpoH} P 3$ using cell-free extracts}

We prepared microscale extracts (Gross et al. 1976) from rpoD800 cells and assayed their ability to transcribe from $r p o H$ P3 by $\mathrm{S} 1$ mapping the in vitro transcripts. With the $r p o H^{+}$plasmid pKPll as template, the extracts produced a single RNA species that had the same $5^{\prime}$ end as the in vivo P3 transcript (Fig. 1). There was no transcription from the $\sigma^{70}$-controlled $r p o H \mathrm{Pl}$ and $\mathrm{P} 4$ promoters, showing that the in vitro extracts accurately reflected transcription in vivo (Fig. 1). We also tested the

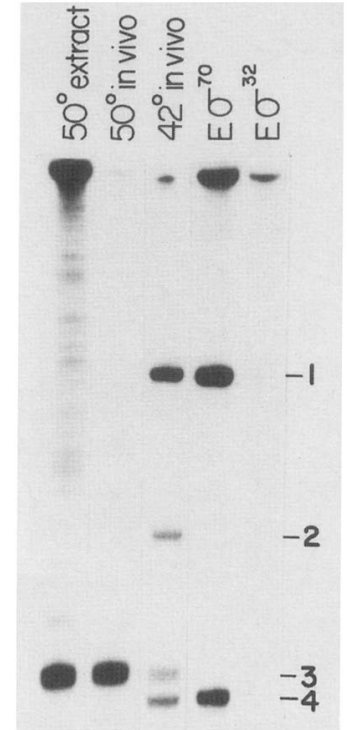

Figure 1. S1 mapping of in vitro and in vivo $r p o H$ transcripts. 5'-End-labeled $r p o H$ probe was hybridized to RNA synthesized in vitro or in vivo and S1 mapped. In vitro RNA was isolated from reactions that contained pKP1l as template, and as sources of RNA polymerase, $5 \mu \mathrm{l}$ of an extract prepared from rpoD800 cells that had been shifted from 30 to $50^{\circ} \mathrm{C}$ for $45 \mathrm{~min}$,

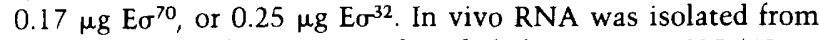
strain SC122 either 20 min after shift from 30 to $42^{\circ} \mathrm{C}(40 \mu \mathrm{g}$ RNA used in the hybridization) or $60 \mathrm{~min}$ after shift to $50^{\circ} \mathrm{C}(5$ $\mu \mathrm{g}$ RNA used in the hybridization). The protected fragments corresponding to the transcripts initiated from $r p o H \mathrm{P} 1, \mathrm{P} 3$, and $\mathrm{P} 4$ are marked, as is the fragment corresponding to the $\mathrm{SC1} 22$. specific transcript mRNA-2 (Erickson et al. 1987).

$50^{\circ} \mathrm{C}$ extracts for the presence of $\mathrm{E}^{32}$ by looking for transcripts from the $\mathrm{E}^{32}$-dependent promoters dnaK Pl and groE pHS (Cowing et al. 1985). As expected, E $\sigma^{32}$ was present in the $50^{\circ} \mathrm{C}$ extracts (data not shown), but pure $\mathrm{E}^{32}$ does not recognize P3 (Erickson et al. 1987; Fujita and Ishihama 1987).

Although S1 mapping was appropriate to identify an extract that contained the factor that recognizes $\mathrm{P} 3$, it was a laborious way to assay a large number of fractions during a purification. We simplified the transcription assay by cloning the rpoH promoters in front of an efficient $\rho$-independent transcription terminator, so that transcripts initiated from each promoter could be distinguished directly, based on their sizes. With plasmid pJET4l /containing the rpoH promoters and the terminator) as a template, the transcripts initiated from $r p o H$ P1, P3, and P4 are 428, 295, and 290 nucleotides, respectively. The data in Figure 2 demonstrate the validity of the transcription assay. When $50^{\circ} \mathrm{C}$ extracts (prepared from both $r p o D^{+}$and rpoD800 cells) were used to transcribe pJET41, a single RNA species of $\sim 295$ bases was produced (Fig. 2). This RNA was shown to originate from $r p o H$ P3 by S1 mapping (data not shown) and by comparison with the 428- and 290-base transcripts made in vitro by $\mathrm{E}^{70}$ (Fig. 2). This more sensitive assay confirmed that the extracts contained no $\sigma^{70}$ activity be- 


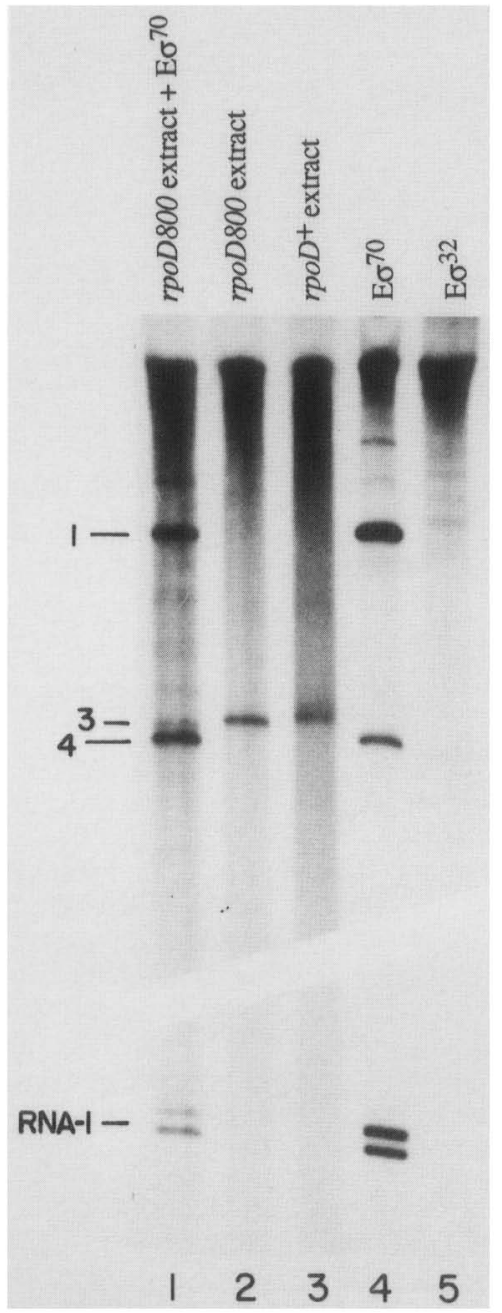

Figure 2. Transcription from the $r p o H$ promoters in vitro. In vitro transcription reactions contained supercoiled pJET41 as template and the following sources of RNA polymerase: extracts $\left(5 \mu \mathrm{l}\right.$ each) prepared from $r p o D^{+}$or rpoD800 cells that had been shifted from 30 to $50^{\circ} \mathrm{C}$ for $45 \mathrm{~min}$ (lanes 1-3), $0.1 \mu \mathrm{g}$ pure $\mathrm{E \sigma}^{70}$ (lanes 1 and 4), or $0.2 \mu \mathrm{g} \mathrm{E \sigma}^{32}$ (lane 5). Pure $\mathrm{E} \sigma^{70}$ was added to the $50^{\circ} \mathrm{C}$ extract in the reaction loaded in lane 1 . RNA samples labeled with ${ }^{32} \mathrm{P}$ were concentrated and electrophoresed as described in Materials and methods. The transcripts from the rpoH P1, P3, and P4 promoters are marked, as are the plasmid ori region RNA-1 transcripts. The central portion of the micrograph has been removed to allow a larger image to be shown.

cause there was no transcription from $r p o H \mathrm{P} 1$ or $\mathrm{P} 4$, or from the plasmid RNA-1 promoter.

\section{Fractionation of the transcription extracts}

Preliminary experiments using the microscale $50^{\circ} \mathrm{C}$ extracts indicated that the factor that recognized $\mathrm{P} 3$ copurified with RNA polymerase on single-stranded DNA agarose and DEAE-cellulose columns but that it was separated into two components on a Bio-Rex 70 column (data not shown). To obtain sufficient material to iden- tify the factor responsible for transcription from $\mathrm{P} 3$, we scaled up the purification, using standard techniques for the large-scale isolation of RNA polymerase (Burgess and Jendrisak 1975). We found that the activity that transcribes from $r p o H$ P3 copurified with core RNA polymerase through chromatography on single-stranded DNA agarose, Sephacryl S-400, and DEAE-cellulose resins (data not shown). When the pooled fractions from the DEAE column were passed through a Bio-Rex 70 column, none of the resulting fractions retained the ability to recognize P3. The flowthrough fraction was inactive (as expected, because it should lack core RNA polymerasel, as was the $0.6 \mathrm{M} \mathrm{NaCl}$ eluate, which contained core RNA polymerase (Fig. 3).

Because $\sigma^{70}$ can be separated from core RNA polymerase on Bio-Rex 70 (Lowe et al. 1979), we wanted to determine whether the P3 activity had been separated into a $\sigma$ and a core component. When the flowthrough fraction and the $0.06 \mathrm{M} \mathrm{NaCl}$ eluate were mixed, the ability to transcribe from $r p o H$ P3 was restored (Fig. 3), suggesting that the activity had been separated into a $\sigma$-factor and core RNA polymerase. This was confirmed by mixing the flowthrough fraction with pure core RNA polymerase and demonstrating that the mixture transcribed from the $r p o H$ P3 promoter (Fig. 3).

To assess the purity of the P3-specific factor, we separated the proteins from the Bio-Rex 70 column fractions on an sodium dodecyl sulfate (SDS)-polyacrylamide gel, and silver stained it (Wray et al. 1981) to visualize the proteins. The fraction that was loaded onto the Bio-Rex 70 column consisted of core RNA polymerase, with a few minor contaminants. The $0.6 \mathrm{M} \mathrm{NaCl}$ eluate was almost indistinguishable from the fraction that was loaded onto the column, whereas the highly purified flowthrough fraction contained $<1 \%$ of the total protein (Fig. 4). To identify the proteins in the flowthrough fraction, we loaded 150 times more sample on an SDS-polyacrylamide gel, silver stained it, and observed a number of proteins, including the $\alpha-, \beta-$, and $\beta^{\prime}$-subunits of RNA polymerase (Fig. 4). This result was surprising, as the flowthrough fraction appeared to be dependent on added core RNA polymerase. We do not have a good explanation for the presence of the core subunits. It is not due to overloading the Bio-Rex 70 column because none of the flowthrough fraction was retained on a second Bio-Rex 70 column (data not shown). It may be that inactive core or proteolyzed subassemblies of RNA polymerase do not bind to Bio-Rex 70 and appear in the flowthrough fraction.

\section{Identification of a $24-\mathrm{kD}$ protein as the $\mathrm{rpoH}$ P3-specific $\sigma$-factor}

To identify which of the proteins present in the Bio-Rex 70 flowthrough fraction was the $\sigma$-factor, we purified the proteins by eluting them from SDS-polyacrylamide gels and renatured them using the procedure of Hager and Burgess (1980). Figure 5 (left) shows a silver-stained SDS-polyacrylamide gel identical to the Coomassieblue-stained gel that was used as the source of protein. 

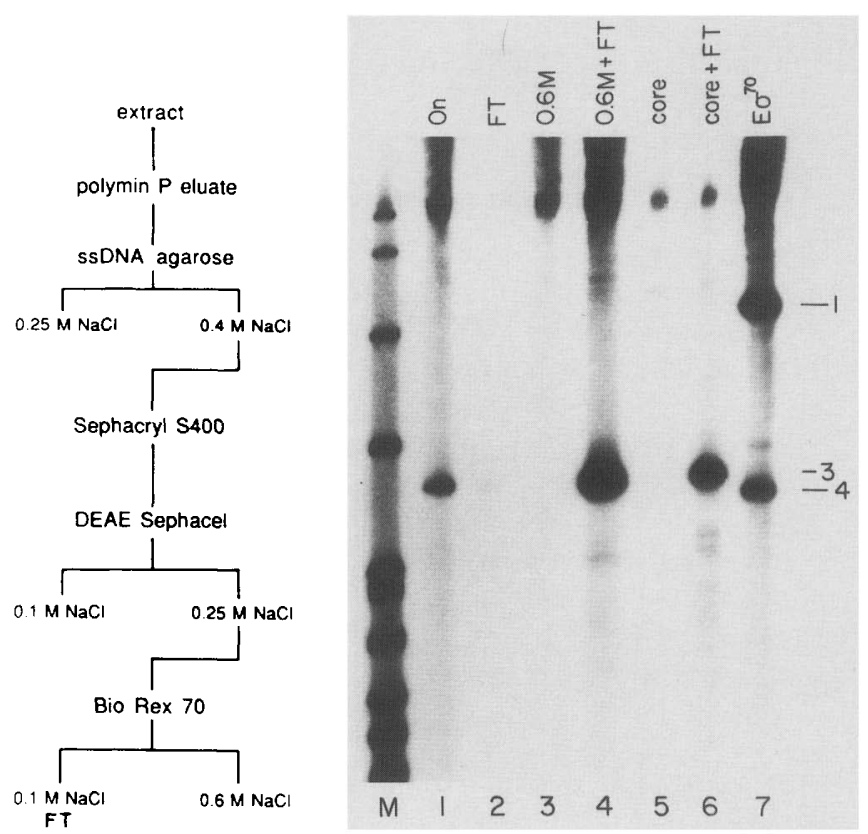

The gel was cut into seven slices covering the molecular weight range from 36,000 to 16,500 , and the proteins in each gel slice were eluted, renatured, mixed with pure core RNA polymerase, and assayed for activity. The only protein capable of directing transcription from the $r p o H$

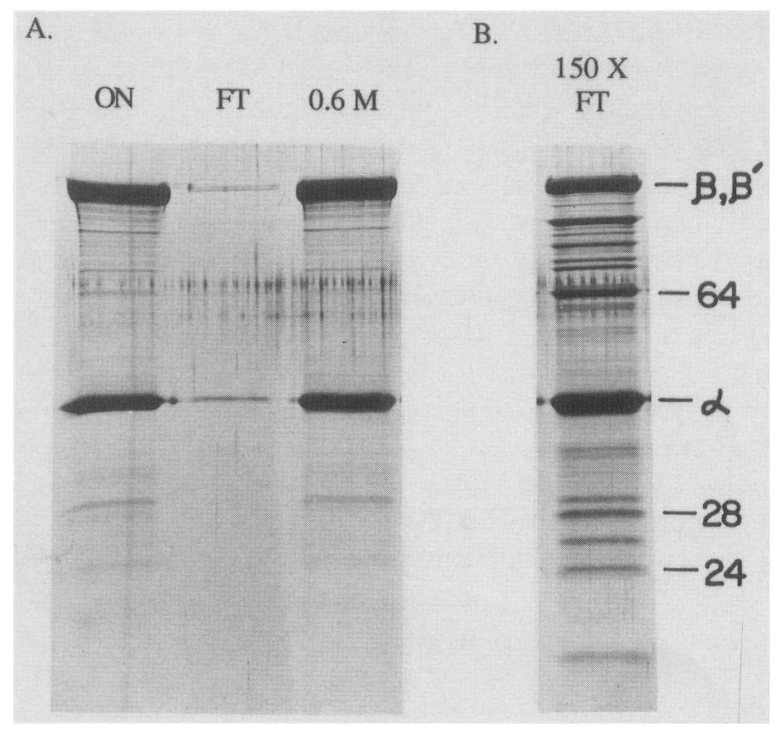

Figure 4. Proteins present in the Bio-Rex 70 column fractions. (A) Proportional volumes of the Bio-Rex 70 onput (ON), flowthrough (FT), and $0.6 \mathrm{M} \mathrm{NaCl}$ eluate $(0.6 \mathrm{M})$ were electrophoresed in $13 \%$ polyacrylamide-SDS gels, and the proteins were visualized by silver staining. $(B)$ A volume of the flowthrough fraction 150 times greater than that loaded in $A$ was concentrated by precipitation with trichloroacetic acid and treated as in $A$. The $\beta-, \beta^{\prime}$-, and $\alpha$-subunits of RNA polymerase are indicated. The molecular weights indicated were determined by comparison with the mobility of bovine serum albumin (BSA) (66 kD), ovalbumin (43 kD), $\alpha$-chymotrypsin $(25$ $\mathrm{kD}$ ), $\beta$-lactoglobulin (18 kD), and lysozyme (14 kD) (not shown).
Figure 3. Purification of the $r p o H$ P3-specific transcription factor. (Left) Schematic diagram of the purification strategy; (right) transcription from $r p o H$ P3 with Bio-Rex 70 column fractions. In vitro reactions contained pJET41 as template, and as sources of protein, $2 \mu \mathrm{l}$ of the Bio-Rex 70 onput (lane 1), $4 \mu \mathrm{l}$ of the Bio-Rex 70 flowthrough (lane 2), $0.6 \mu$ l of the $0.6 \mathrm{M} \mathrm{NaCl}$ eluate from the Bio-Rex 70 column (lane 3), $4 \mu$ l of flowthrough and $0.6 \mu \mathrm{l}$ of the $0.6 \mathrm{M}$ eluate (lane 4 ), $0.6 \mu \mathrm{g}$ pure core RNA polymerase (lane 5), $0.6 \mu \mathrm{g}$ core RNA polymerase mixed with 4 $\mu \mathrm{l}$ of the Bio-Rex 70 flowthrough fraction (lane 6), or $0.3 \mu \mathrm{g}$ pure $\mathrm{E \sigma}^{70}$ holoenzyme (lane 7). The positions of the transcripts from the $r$ oH P1, P3, and P4 promoters are marked. (Lane $M$ ) DNA size markers of $622,527,404,309,242,238,217,201$, and 190 nucleotides (5'-end-labeled HpaII digest of pBR322).

P3 promoter was contained in slice 5, implicating the strongly stained $24-\mathrm{kD}$ protein as the P3-specific $\sigma$ factor (Fig. 5). In similar experiments, proteins ranging from 14 to $200 \mathrm{kD}$ were examined with the same result - only the protein in the gel slice containing the $24-\mathrm{kD}$ protein was active in stimulating transcription from rpoH P3.

To confirm our identification of the $24-\mathrm{kD}$ protein as the P3-specific $\sigma$-factor, we repeated the SDS-polyacrylamide gel renaturation experiment using proteins eluted from a silver-stained gel. Silver staining allowed the precise excision of the $24-\mathrm{kD}$ protein, as well as several gel slices above and below it. Once again, $\sigma$ activity was recovered only from the gel slice that contained the $24-\mathrm{kD}$ protein (data no shown). The efficiency of elution and renaturation from the silver-stained gel was $\sim 100$-fold lower than from unstained or Coomassie-blue-stained gels, but the activity was easily distinguished from the background.

Our experiments demonstrate that the $24-\mathrm{kD}$ protein is a novel RNA polymerase $\sigma$-factor. The purified protein confers a unique promoter specificity upon core RNA polymerase, and it has a different mobility on SDS-polyacrylamide gels $(24 \mathrm{kD})$ than the previously identified $E$. coli $\sigma$ factors, $\sigma^{70}(90 \mathrm{kD}), \sigma^{54}(75 \mathrm{kD}), \sigma^{32}$ $(32 \mathrm{kD})$, and $\sigma^{\mathrm{F}}(28 \mathrm{kD})$ (Lowe et al. 1979; Grossman et al. 1984; Hunt and Magasanik 1985; Arnosti and Chamberlin 1989).

Originally, $\sigma$-factors were named with a superscript designating the molecular weight of the protein as estimated from its mobility on SDS-polyacrylamide gels. This has become confusing because most $\sigma$-factors were renamed when their true molecular weights were established. To avoid similar problems, we will call the 24-kD $\sigma$-factor, $\sigma^{\mathrm{E}}$, with the expectation that the gene encoding it will be named rpoE in accordance with the accepted nomenclature (Hayward and Scaife 1976). 


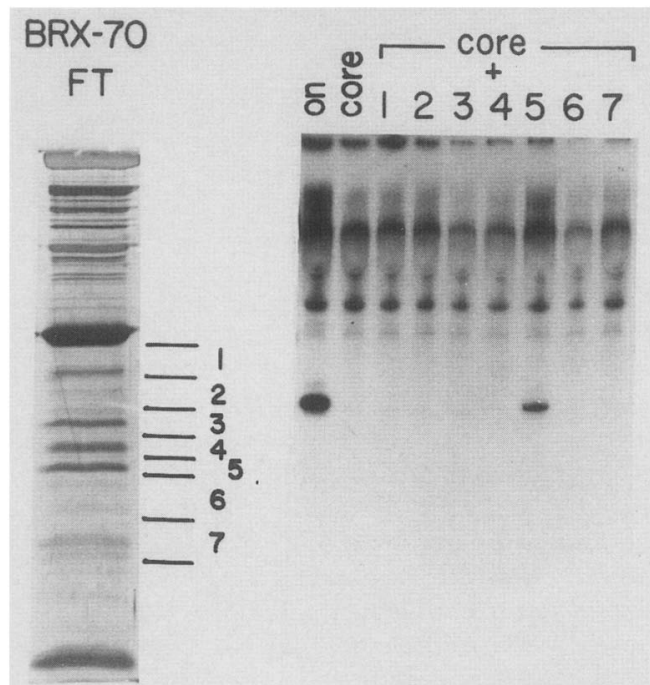

Figure 5. Renaturation of the P3-specific o-factor after SDS-polyacrylamide gel electrophoresis. (Left) A silver-stained $13 \%$ polyacrylamide -SDS gel containing a $100 \mu \mathrm{l}$ sample of the flowthrough fraction from the Bio-Rex 70 column. A protein sample identical to the one shown was stained with Coomassie blue, and the Coomassie-stained lane was cut into sections as indicated. The proteins from gel sections $1-7$ were eluted, renatured $(765 \mu \mathrm{l}$ total volume), and assayed for $\sigma$-factor function. (Right) In vitro transcription assays with the proteins eluted from the SDS-polyacrylamide gel. pJET41 was transcribed with $0.3 \mu \mathrm{g}$ of core RNA polymerase plus $3 \mu \mathrm{l}$ of the Bio-Rex 70 flowthrough (lane on), core RNA polymerase alone (lane core), or core RNA polymerase supplemented with $25-\mu$ l samples $33.3 \%$ of the total $)$ of the proteins eluted from gel sections $1-7$ (lanes core $+1-7$ ). In this experiment the transcription reactions contained $33 \mathrm{mM}$ Tris (pH 7.9), $8 \mathrm{~mm} \mathrm{MgCl}, 140 \mu \mathrm{g} / \mathrm{ml}$ BSA, $160 \mathrm{~mm} \mathrm{NaCl}, 0.8 \mathrm{~mm}$ EDTA, $1 \mathrm{~mm}$ DTT, 5\% glycerol, and $27 \mathrm{mM}$ guanidine hydrochloride.

\section{Structure of the rpoH $P 3$ promoter}

The $\sigma^{\mathrm{E}}$-controlled P3 and the $\sigma^{70}$-controlled P4 promoters overlap extensively. To distinguish the two promoters and to isolate and identify $\mathrm{P} 3$, we constructed deletions that eliminated $\mathrm{P} 4$ function but that retained a functional P3. To eliminate P4, we synthesized two double-stranded oligonucleotides that lack a portion of the predicted -10 region of $\mathrm{P} 4$ but should contain all of P3. These oligonucleotides were cloned in front of a promoterless galK gene, creating pIEK60 and pJEK61 (Fig. 6). Galactokinase was expressed from both plasmids in vivo, suggesting that the $\mathrm{P} 3$ promoter was functional. This was confirmed in three ways. First, galactokinase synthesis was measured in vivo by pulse-labeling and was found to be induced by shift to 43 or $50^{\circ} \mathrm{C}$ (data not shown). Second, RNA was isolated from cells carrying pJEK60 or pJEK61, both at $30^{\circ} \mathrm{C}$ and after shift to $50^{\circ} \mathrm{C}$, and then S1 mapped. In both strains a major plasmid-encoded transcript of the correct size was found, and these transcripts were induced strongly after shift to $50^{\circ} \mathrm{C}$ /Fig. 6). Third, E ${ }^{\mathrm{E}}$ recognized the P3 promoters of pJEK60 and pJEK61 and synthesized transcripts in vitro that were identical to those made in vivo. No specific transcripts were detected from either plasmid using $\mathrm{E \sigma}^{70}$, confirming that the $\mathrm{P} 4$ promoter was destroyed in the cloning (Fig. 6).

\section{A second $\sigma^{E}$-controlled promoter}

Transcription of the E. coli htrA (high temperature requirement) gene is induced independently of $r p o H$ and $\sigma^{32}$, by exposure to high temperature (Lipinska et al. 1988). When Lipinska et al. (1988) sequenced the htrA promoter, they noted a striking resemblance to the sequence of rpoH P3 and proposed that $h t r A$ would be transcribed by E $\sigma^{\mathrm{E}}$. The $\mathrm{S} 1$ mapping experiment shown in Figure 7 confirms that the $h t r A$ promoter is recognized by $E \sigma^{\mathrm{E}}$. In vivo, the $h t r A$ transcript is induced after shift from 30 to $50^{\circ} \mathrm{C}$. In vitro, the htrA transcript is synthesized by $E \sigma^{E}$ but not by $E \sigma^{70}$ (Fig. 7). These experiments and those of Lipinska et al. (1988) establish htrA as the second $E$. coli gene known to be transcribed by $E \sigma^{\mathrm{E}}$.

The sequences of the $h t r A$ and $r p o H \mathrm{P} 3$ promoters are shown in Figure 8A. There are four segments of common sequence in the two promoters. The sequence GAACTT probably corresponds to the upstream $(-35)$ portion of each promoter, and the sequence TCTGA most likely represents the downstream $(-10)$ region. The probable -10 and -35 regions are separated by a spacer of $16 \mathrm{bp}$. The spacer regions of both promoters contain the sequence ATAAA, but its position is offset by $2 \mathrm{bp}$ in one promoter relative to the other. The sequences near the transcription start sites are also similar; however, these sequences are not required for promoter function (Fig. 6)

The sequences of the rpoH $\mathrm{P} 3$ and $h t r A$ promoters do not resemble any of the known E. coli or Bacillus promoter consensus sequences (Helmann and Chamberlin 1988). They do, however, resemble the $\operatorname{dag} A$ (agarase) P1 and P2 promoters from Streptomyces coelicolor (Buttner et al. 1988), and the phl (phospholipase Al) promoter of Serratia liquefaciens (Givskov et al. 1988) (Fig. 8B). The $\operatorname{dag} A \mathrm{P} 2$ promoter is recognized by the minor $\mathrm{E}^{28}$ form of $S$. coelicolor RNA polymerase, but it is not known which holoenzyme transcribed from the P1 promoter (Buttner et al. 1988).

The $S$. liquefaciens phl promoter is known to be expressed in E. coli (Givskov et al. 1988), but we know of no published information regarding its activity at high temperature in either organism.

\section{Discussion}

\section{Purification of $\boldsymbol{\sigma}^{E}$}

We identified and purified a novel $E$. coli $\sigma$-factor, which we call $\sigma^{\mathrm{E}}$. RNA polymerase containing $\sigma^{\mathrm{E}}$ recognizes the P3 promoter of $r p o H$, the gene that encodes $\sigma^{32}$, the heat shock $\sigma$-factor. E $\sigma^{\mathrm{E}}$ was purified by chromatography on single-stranded DNA agarose, Sephacryl S-400, and DEAE-Sephacryl. The $\sigma^{\mathrm{E}}$ subunit was separated from core RNA polymerase by chromatography on Bio-Rex 70 . To prove that $\sigma^{\mathrm{E}}$ functions as a $\sigma$-factor and that it is distinct from any of the known $\sigma$-factors, we isolated the 
Figure 6. Isolation of the $r p o H$ P3 promoter. (Top) DNA sequence of the region containing the rpoH P3 and P4 promoters. The nontemplate strand is shown. The -35 and -10 regions of the $\sigma^{70}$-controlled $r p o H$ P4 promoter are underlined, and the transcription start sites are marked with the numbered arrows. Plasmid pJEK5 contains an additional $62 \mathrm{bp}$ from the $r p o H$ locus to the right of the sequence shown. Plasmids pJEK60 and pJEK61 contain the 40- and 37-bp sequences shown and no additional $r p o H$ DNA. The plasmid-derived sequence that abuts the right-hand end of the rpoH DNA in both plasmids is CTAGAGGATCCCC. (Bottom) Sl mapping of in vitro and in vivo transcripts from pJEK60 and pJEK61. DNA probes were prepared from pJEK60 and pJEK61 and were 5'-end-labeled at the BssHII site in the vector located $250 \mathrm{nu}^{-}$ cleotides downstream from the $3^{\prime}$ end of the rpoH P3 promoter insert. In vitro RNA was prepared from transcription reactions that contained $0.85 \mu \mathrm{g}$ of $\mathrm{E \sigma}^{70}, 0.5 \mu \mathrm{g}$ of $\mathrm{E \sigma}^{32}$, or 0.7 of $\mu \mathrm{g}$ core RNA polymerase plus $8 \mu \mathrm{l}$ of the BioRex 70 flowthrough $\left(E \sigma^{\mathrm{E}}\right)$. In vivo RNA was extracted from cells grown at $30^{\circ} \mathrm{C}$ or $20 \mathrm{~min}$ after shift to $50^{\circ} \mathrm{C}$. Hybridizations contained $10 \mu \mathrm{g}$ of $30^{\circ} \mathrm{C}$ RNA or $5 \mu \mathrm{g}$ of $50^{\circ} \mathrm{C}$ RNA. rpoH P3 transcripts (indicated by arrows) initiate within the vector sequences immediately 3 ' of the insert and should protect fragments of $\sim 247$ nucleotides (pJEK60) or $\sim 244$ nucleotides (pJEK61). The 3-base difference in lengths of protected fragments derive from the different sizes of the inserts in the two plasmids. The origins of the smaller protected fragments in the in vivo RNA lanes are not known but may reflect processing or degradation of these plasmid-derived transcripts.

protein from SDS-polyacrylamide gels, renatured it, and showed that renatured $\sigma^{\mathrm{E}}$ directed core RNA polymerase to initiate transcription from $r p o H$ P3 in vitro.

\section{Promoter specificity of $\mathrm{E \sigma}^{\mathrm{E}}$}

RNA polymerase containing $\sigma^{\mathrm{E}}$ has a unique promoter specificity. $E \sigma^{\mathrm{E}}$ did not initiate transcription from the three $\sigma^{70}$-controlled promoters we tested (Figs. $1-3$, and 5) or from the $\sigma^{32}$-controlled promoters; dnaK Pl, groE pHS, and $r p o D$ pHS (data not shown). So far we have found two promoters that are recognized by $E \sigma^{\mathrm{E}}$ : the $E$. coli rpoH P3 and the htrA promoters. The sequences of the $\sigma^{\mathrm{E}}$-controlled promoters are shown in Figure 8A. The sequence comparison suggests that, as with most types of bacterial promoters, $\sigma^{\mathrm{E}}$-controlled promoters have conserved sequences that are analogous to the -10 and -35 regions of $\sigma^{70}$-controlled promoters (Reznikoff et al. 1985; Helmann and Chamberlin 1988). In addition, the sequence ATAAA, located between the putative - 10 and -35 regions is present in both promoters. The sequences of these conserved regions are different from the known $\sigma^{70_{-}}, \sigma^{32}{ }_{-}, \sigma^{F_{-}}$, or $\sigma^{54}$-controlled promoters (Hawley and McClure 1983; Cowing et al. 1985; Arnosti and Chamberlin 1989; Ninfa et al. 1989). Consistent with the differences in promoter sequences, neither $\mathrm{E}^{70}$ nor $\mathrm{E}^{32}$ transcribes from the $h$ tr $A$ or $r p o H$ P3 promoters in vitro (Erickson et al. 1987; Figs. 1, 2, and 7). Our results conflict with those of Fujita and Ishihama (1987), who reported that $\mathrm{P} 3\left(\mathrm{P} 2^{\circ}\right.$ in their paper) was recognized by $\mathrm{E \sigma}^{70}$. Their claim was based on low-level in vitro transcription from $\mathrm{P} 3$ by $E \sigma^{70}$. We believe their results were due to contamination with $\mathrm{E}^{\mathrm{E}}$ because none of the steps in their RNA polymerase purification would have separated $E \sigma^{70}$ and $E \sigma^{\mathrm{E}}$.

The existence of $\sigma^{E}$ explains the synthesis of the heat shock proteins at lethal temperatures

At $50^{\circ} \mathrm{C}$, a temperature too high for growth and lethal under prolonged exposure, the heat shock proteins are virtually the only proteins synthesized (Neidhardt et al. 1984; Paek and Walker 1986). Neidhardt et al. (1984) suggested originally that the exclusive synthesis of the heat shock proteins could occur if $\sigma^{32}$ was active and $\sigma^{70}$ was inactive at $50^{\circ} \mathrm{C}$. This proposal now has experimental support. First, there is no transcription from the $\sigma^{70}$-controlled $r p o H ~ P l$ and $\mathrm{P} 4$ promoters at times after shift to $50^{\circ} \mathrm{C}$ when the $\sigma^{32}$-controlled groE $\mathrm{pHS}$ promoter remains active (Erickson et al. 1987; unpubl.). Second, transcription extracts prepared from cells shifted to $50^{\circ} \mathrm{C}$ contain active $\sigma^{32}$ but do not contain detectable $\sigma^{70}$ activity (Fig. 2; data not shown). The decrease in $\sigma^{70}$ activity may seem paradoxical, given that $\sigma^{70}$ is a heat shock protein; however, there are other suggestions that $\sigma^{70}$ is less active at high temperature. Skelly et al. (1987) quantified the amount of $\mathrm{E}^{70}$ in extracts made from cells shifted from 33 to 40 or $45^{\circ} \mathrm{C}$ and found that it decreased with increasing temperature. Although the amount of $E \sigma^{70}$ decreased, the amount of $\sigma^{70}$ protein in the extracts increased, suggesting that at high temperatures a modification of $\sigma^{70}$, or of core, prevents or de- 


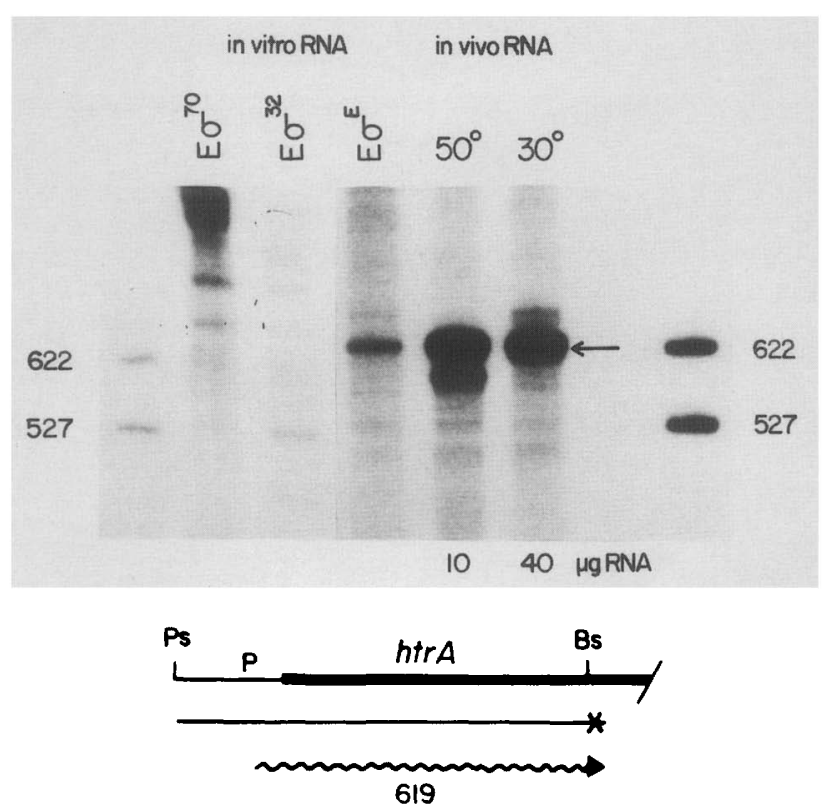

Figure 7. $E \sigma^{\mathrm{E}}$ transcribes from the $h \operatorname{tr} A$ promoter. Comparison of in vivo and in vitro $h$ trA transcripts by $\mathrm{S} 1$ mapping. The schematic diagrams the S1 mapping strategy. A 778-bp PstI (Ps)-BstEII (Bs) DNA fragment from pBL133, 5'-end-labeled at the $B$ stEII site, was used as probe. Transcripts initiated from the htrA promoters should protect a 619-nucleotide fragment (arrow) from digestion by $\mathrm{S} 1$ nuclease. In vitro RNA was synthesized with $0.43 \mu \mathrm{g}$ of $\mathrm{E \sigma}^{70}, 0.5 \mu \mathrm{g}$ of $\mathrm{E}^{32}$, or $0.35 \mu \mathrm{g}$ of core RNA polymerase plus $2 \mu \mathrm{l}$ of the Bio-Rex 70 flowthrough $\left(E \sigma^{\mathrm{E}}\right)$, using pBL133 as template. In vivo RNA was isolated from strain $\mathrm{SCl} 22$ grown at $30^{\circ} \mathrm{C}$ or $20 \mathrm{~min}$ after shift to $50^{\circ} \mathrm{C}$. Hybridizations were done with $40 \mu \mathrm{g}$ of $30^{\circ} \mathrm{C}$ RNA and $10 \mu \mathrm{g}$ of $50^{\circ} \mathrm{C}$ RNA. DNA size markers of 622 and 527 nucleotides are present in the flanking lanes. The origin of the smaller protected fragment in the $50^{\circ} \mathrm{C}$ lane is not known, but it may reflect degradation of the RNA at the lethal temperature.

creases the association of $\sigma^{70}$ with core RNA polymerase.

$\sigma^{32}$ is degraded rapidly at $50^{\circ} \mathrm{C}$ (A. Grossman, W. Walter, and C. Gross, unpubl.) and must therefore be synthesized continuously if the cell is to maintain the expression of the heat shock genes. Because $\sigma^{32}$ is not autoregulatory (Bloom et al. 1986; Tilly et al. 1986; Erickson et al. 1987; Fujita and Ishihama 1987), it was not clear how its synthesis could be maintained at $50^{\circ} \mathrm{C}$ if the $\mathrm{rpoH}$ promoters were recognized solely by the $\mathrm{E}^{70}$. Our demonstration that $r p o H$ P3 is recognized by $\mathrm{E \sigma}^{\mathrm{E}}$, which is active at $50^{\circ} \mathrm{C}$, explains this aspect of the heat shock response. It is the transcription from the $\sigma^{\mathrm{E}}$-dependent $r p o H$ P3 promoter that allows $\sigma^{32}$ to be made and the heat shock genes to be transcribed at $50^{\circ} \mathrm{C}$.

\section{$\sigma^{E}$ and the regulation of $\mathrm{rpoH}$ transcription}

At normal growth temperatures, the transcripts from $\mathrm{P} 3$ represent a small fraction of the $r p o H$ mRNA. This fraction increases with increased temperature, but even at $43.5^{\circ} \mathrm{C}$, the transcript from $\mathrm{P} 3$ represents only $\sim 15 \%$ of the total $r p o H$ mRNA (Erickson et al. 1987; Fujita and Ishihama 1987; J. Erickson and C. Gross, unpubl.). We argued previously (Erickson et al. 1987; Straus et al. 1987) that the transcription of $r p o H$ is of little regulatory significance for the heat shock response. This is because the increase in $r p o H$ mRNA synthesis after temperature upshift (Erickson et al. 1987) is too slow and too small to account for the transient 20 -fold increase in $\sigma^{32}$ concentration that leads to the heat shock response (Straus et al. 1987). Our argument did not, however, imply that the increased transcription of $\mathrm{rpoH}$ after temperature upshift is unimportant. In fact, it is likely that the level of $r p o H$ mRNA determines the steady-state level of $\sigma^{32}$, because there is a good correlation between the steadystate amount of $\sigma^{32}$ and the rpoH mRNA concentration (Erickson et al. 1987; Straus et al. 1987; D. Straus, J. Erickson, and C. Gross, unpubl.). Viewed in this way, the role of $\sigma^{\mathrm{E}}$ in $r p o H$ transcription is as part of the mechanism that determines the amount of $r p o H$ transcription appropriate for the growth temperature. At low temperatures the contribution of $\sigma^{\mathrm{E}}$ is small, but as the temperature increases, it becomes quantitatively more important as transcription from P3 is induced and the amount of active $\sigma^{70}$ declines.

\section{A second heat shock regulon}

The $h \operatorname{tr} A(\operatorname{deg} P)$ gene is required for growth and survival of $E$. coli at temperatures $>42^{\circ} \mathrm{C}$ (Lipinska et al. 1989). $h \operatorname{tr} A$ encodes a $51-\mathrm{kD}$ precursor protein that is processed to the $48-\mathrm{kD}$ periplasmic protease DegP (Strauch and Beckwith 1988; Lipinska et al. 1989). The exact function of DegP is not known, but strains with an $h \operatorname{tr} A:: \operatorname{Tn} 10$ insertion cease macromolecular synthesis and lyse soon after shift to high temperature (Lipinska et al. 1989).

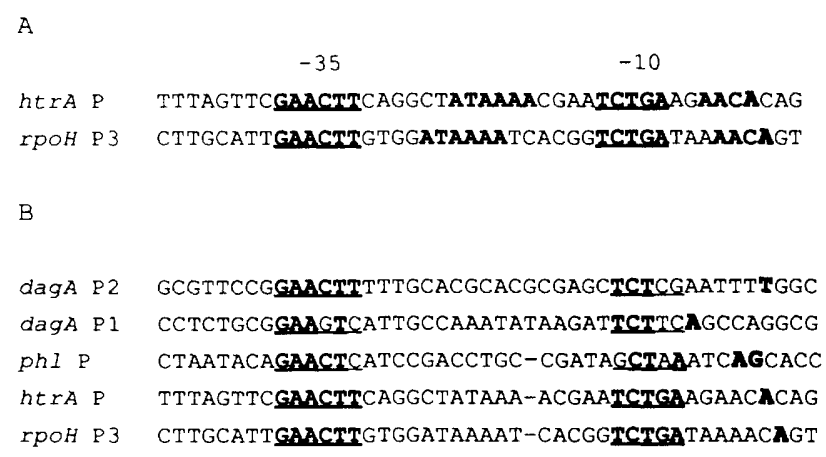

Figure 8. Comparison of the DNA sequences of the $h t r A$ and $\mathrm{rpoH}$ P3 promoters with other promoters that may be recognized by $\mathrm{E}^{\mathrm{E}}$. $(A)$ The $E$. coli htrA and $r p o H$ P3 promoter sequences. The nontemplate strands are shown. The transcription start sites are outlined, and the common sequences are shown in boldface type. The putative -10 and -35 regions are underlined. $(B)$ DNA sequences of three heterologous promoters that are similar to the $\sigma^{\mathrm{E}}$-controlled $h t r A$ and $r p o H$ P3 promoters. The start points of transcription are outlined and common sequences in the putative -10 and -35 regions are shown in boldface type. The $\operatorname{dag} A \mathrm{Pl}$ and $\mathrm{P} 2$ promoters are from S. coelicolor (Buttner et al. 1988), and the phl promoter is from S. liquefaciens (Givskov et al. 1988). 
Transcription of $h t r A$ is induced strongly in vivo after shift to high temperature, but the increased transcription is independent of $\sigma^{32}$ (Lipinska et al. 1988). Lipinska et al. (1988) mapped the $5^{\prime}$ end of the htrA transcript and found that the sequence of the putative promoter was almost identical to $r p o H$ P3. Using the criteria of in vitro transcription by pure $\mathrm{E}^{\mathrm{E}}$ and induction of transcription after shift to $50^{\circ} \mathrm{C}$ in vivo, we confirmed that the $h t r A$ promoter is recognized by $\mathrm{E \sigma}^{\mathrm{E}}$ (Fig. 7), making it the second $E$. coli gene known to be under the control of $\sigma^{\mathrm{E}}$.

Given that $\sigma$-factors tend to regulate global changes in gene expression, we think it unlikely that the rpoH P3 and the $h \operatorname{tr} A$ promoters are the only ones recognized by $E \sigma^{\mathrm{E}}$. Until now, most studies of gene expression at high temperature have focused on the heat shock genes, which are under the control of $r p o H$ and transcribed by $E \sigma^{32}$. The emphasis on the heat shock genes has obscured the fact that there are a number of $\sigma^{32}$-independent genes that are expressed at higher levels after shift to high temperature (Herendeen et al. 1979; Neidhardt et al. 1982, 1983; Yamamori and Yura 1982; Neidhardt and VanBogelen 1987|. We believe that some of these genes are transcribed by $\mathrm{E}^{\mathrm{E}}$ and constitute a second group of coordinately regulated heat-inducible genes.

The existence of this second high-temperature regulon raises a problem with existing terminology. Previously, the term "heat shock genes," has been used to describe only those genes that are regulated by $\sigma^{32}$ and are heat inducible. To avoid confusion, we suggest that the different heat-inducible genes should be referred to as $\sigma^{32}$ or $\sigma^{\mathrm{E}}$ dependent in cases of ambiguity.

\section{What is the role of $\mathbf{\sigma}^{E}$ ?}

What are the likely functions of $\sigma^{\mathrm{E}}$ ? It is clear that the $\sigma^{\mathrm{E}}$-controlled $h$ trA gene is required for growth and survival at temperatures $>42^{\circ} \mathrm{C}$ (Lipinska et al. 1989) and that the $\sigma^{\mathrm{E}}$-dependent transcription of $r p o H$ is necessary for the synthesis of $\sigma^{32}$ at lethal temperatures; therefore, we expect that other $\sigma^{\mathrm{E}}$-controlled genes will have functions related to growth or survival at high temperature. One possible function for $\sigma^{\mathrm{E}}$ is in thermotolerance, i.e., the inducible resistance to killing at high temperature. Until recently, it was thought that the heat shock proteins were the primary components of thermotolerance; however, it has now been demonstrated that the induction of the heat shock genes is not sufficient to induce thermotolerance (VanBogelen et al. 1987a). One implication of these results is that treatments inducing thermotolerance must induce or activate a set of proteins distinct from the heat shock proteins. Transcription by $\mathrm{E}^{\mathrm{E}}$ is increased by some of the conditions that induce thermotolerance, such as a shift to $42^{\circ} \mathrm{C}$ (Erickson et al. 1987; Fujita and Ishihama 1987) or addition of ethanol to $10 \%$ (J. Erickson and C. Gross, unpubl.). E $\sigma^{\mathrm{E}}$ is also active at lethal temperatures, making it a likely candidate to be a regulator of the $\sigma^{32}$-independent genes involved in thermotolerance.

We emphasized possible roles of $\sigma^{\mathrm{E}}$ at high temperatures because of the properties of two $E$. coli genes that are transcribed by E $\sigma^{\mathrm{E}}$. It is also possible that $\sigma^{\mathrm{E}}$ is im- portant at low temperatures. In this regard, the similarity between the ropH $\mathrm{P} 3$ and $h t r A$ promoters and the $S$. coelicolor and $S$. liquefaciens promoters is interesting. If these promoters are recognized by $\mathrm{E \sigma}^{\mathrm{E}}$, the $\sigma$-factors that direct RNA polymerase to recognize these promoters in $S$. coelicolor and $S$. liquefaciens are likely to be homologous to $E$. coli $\sigma^{\mathrm{E}}$. If there is conservation of function among the $\sigma$-factors from these diverse organisms, we may be able to learn something about the function of $E$. coli $\sigma^{\mathrm{E}}$ by analogy. The only connection we know of between the $S$. coelicolor $\operatorname{dag} A, S$. liquefaciens phl, and E. coli htrA genes is that they encode secreted (extracellular or periplasmic) hydrolytic enzymes. It may be that $E \sigma^{\mathrm{E}}$ transcribes a set of genes encoding secreted proteins; however, most of the known genes that encode periplasmic or extracellular proteins appear to be transcribed by $\mathrm{E}^{70}$ (Oliver 1985; Randall et al. 1987).

The available data suggest that $\sigma^{\mathrm{E}}$ can control the synthesis of $\sigma^{32}$ under extreme environmental conditions and that $\sigma^{\mathrm{E}}$ activity is required for survival at high temperature. Transcription by $\mathrm{E}^{\mathrm{E}}$ appears to be induced by high temperature and by exposure to high concentrations of ethanol. When the analysis of the rpoE gene is begun, these observations and the possible connection between $\sigma^{\mathbf{E}}$ and secreted proteins will provide starting places in the search for the functions of $\sigma^{\mathrm{E}}$.

\section{Materials and methods}

Strains and plasmids

Strains SC122 $\left(r p O D^{+}\right)($Cooper and Ruettinger 1975) and CAG510 (SC122 rpoD800) were used as sources of transcription extracts and in vivo rpoH and htrA mRNA. MCl06l $\Delta$ (araCOIBA, leu)7697, araD139, $\Delta($ lac)X74, galK, galU, rpsL) (Casadaban and Cohen 1980), carrying plasmids pJEK60 or pJEK61, was used to analyze expression from the isolated $\mathrm{P} 3$ promoter (Fig. 6). Plasmid pUC19-spf' was made by cloning a 132-bp fragment containing most of the spf gene and its transcription terminator (Joyce and Grindley 1982) into pUC19 (Yanisch-Perron et al. 1985). The HindIII-BamHI portion of the polylinker is located upstream of the terminator so that transcripts terminate either 103 or 104 bases from the last position of the BamHI site. pUC19-spf' carries the $\sigma^{70}$-dependent ColEl RNA-1 promoter, which produces transcripts of 102 and 108 nucleotides. pIET41 was made by inserting a blunt-ended 895-bp SphI-MluI fragment from pKP1l (Paek and Walker 1986; Erickson et al. 1987) that contains the $r p o H$ promoters and the first 22 codons of $r p o H$ into pUC19-spf' that had been cleaved with SphI and Sall and made blunt-ended. The $r p o H \mathrm{P}^{+}-g^{+} K^{+}$fusion plasmids pJEK60 and pJEK61 were made by ligating doublestranded oligonucleotides (synthesized by the University of Wisconsin Biotechnology Center) containing the P3 promoter (Fig. 6) into pKO500 [a derivative of pKOl (McKenney et al. 1981), with the multiple cloning site from M13mpl1] that had been cut with HindIII and XbaI. The sequences of the inserts were confirmed by dideoxy sequencing (Tabor and Richardson 1987). pBL133, which contains the htrA gene, has been described (Lipinska et al. 1988).

\section{Purification of $\sigma^{E}$}

For the large-scale purification of $\sigma^{\mathbf{E}}, \mathrm{CAG} 510$ was grown in a 10-liter fermentor at $30^{\circ} \mathrm{C}$, shifted to $50^{\circ} \mathrm{C}$ for $45 \mathrm{~min}$, chilled 
on ice, and harvested by filtration. The procedure of Burgess and Jendrisak (1975) was used through the $\left(\mathrm{NH}_{4}\right)_{2} \mathrm{SO}_{4}$ precipitation step. The $\left(\mathrm{NH}_{4}\right)_{2} \mathrm{SO}_{4}$ precipitates /starting from 80 grams of cells) were resuspended in TGED $[10 \mathrm{~mm}$ Tris- $\mathrm{HCl}(\mathrm{pH} 7.9)$, $10 \%$ glycerol, $0.1 \mathrm{~mm}$ EDTA, $1 \mathrm{~mm} \mathrm{DTT}$, diluted to a conductivity equal to TGED $+0.25 \mathrm{M} \mathrm{NaCl}$, and loaded onto a $25-\mathrm{ml}$ single-stranded DNA agarose column (Arndt-Jovin et al. 1975). The column was washed with TGED $+0.25 \mathrm{M} \mathrm{NaCl}$, and E $\sigma^{\mathrm{E}}$ was eluted with TGED $+0.4 \mathrm{M} \mathrm{NaCl}$. The fractions were precipitated with $\left(\mathrm{NH}_{4}\right)_{2} \mathrm{SO}_{4}(3.5 \mathrm{~g} / \mathrm{ml})$, resuspended in TGED + $0.4 \mathrm{M} \mathrm{NaCl}$, and loaded onto a 400-ml Sephacryl S-400 column (Lowe et al. 1979). The active fractions were pooled, diluted to TGED $+0.1 \mathrm{M} \mathrm{NaCl}$, and loaded onto a 4-ml DEAE-Sephacel column. E $\sigma^{\mathrm{E}}$ was eluted with TGED $+0.25 \mathrm{M}$ $\mathrm{NaCl}$. The fractions were diluted to TGED $+0.1 \mathrm{M} \mathrm{NaCl}$ and passed through a 4-ml Bio-Rex 70 column. $\sigma^{\mathrm{E}}$ activity was found in the flowthrough fraction and core RNA polymerase was eluted with TGED $+0.6 \mathrm{M} \mathrm{NaCl}$. To purify $\sigma^{\mathrm{E}}$ further portions of the flowthrough were acetone precipitated, resuspended in SDS sample buffer, and electrophoresed through SDS-polyacrylamide gels (Laemmli 1970; Hager and Burgess 1980). $\sigma^{E}$ was identified by staining with Coomassie blue or silver (Wray et al. 1981), cut from the gel, eluted, and renatured as described (Hager and Burgess 1980).

\section{In vitro transcription}

Transcription reactions $(100 \mu \mathrm{l})$ contained $0.3-0.5 \mu \mathrm{g}$ plasmid DNA in $30 \mathrm{~mm}$ Tris- $\mathrm{HCl}$ (pH 7.9), $180 \mathrm{~mm} \mathrm{NaCl}, 10 \mathrm{~mm}$ $\mathrm{MgCl}_{2}, 1 \mathrm{~mm}$ EDTA, $1 \mathrm{~mm}$ DTT, $100 \mu \mathrm{g} / \mathrm{ml}$ of acetylated BSA, $200 \mu \mathrm{M}$ each ATP, GTP, and CTP, and $15 \mu \mathrm{M}$ UTP with 5-10 $\mu \mathrm{Ci}\left[\alpha^{-32} \mathrm{P}\right] \mathrm{UTP}$. Core RNA polymerase, $\mathrm{E}^{70}$, and $\mathrm{E}^{32}$ were prepared as described (Lowe et al. 1979; Erickson et al. 1987). Cell-free transcription extracts (Gross et al. 1976) were made from SC122 or CAG510 that had been shifted from 30 to $50^{\circ} \mathrm{C}$ for $45 \mathrm{~min}$. The step 4 extracts (Gross et al. 1976) were used in the transcriptions. The forms and amounts of RNA polymerase used are noted in the figure legends. Reactions were incubated at $37^{\circ} \mathrm{C}$ for $10 \mathrm{~min}$ and stopped by the addition of $100 \mu \mathrm{l}$ of $[4 \mathrm{M}$ $\mathrm{NH}_{4}{ }^{+}$acetate (pH 7), $40 \mathrm{~mm}$ EDTA, $0.3 \%$ (wt/vol) SDS, 400 $\mu \mathrm{g} / \mathrm{ml}$ tRNA], and precipitated with $220 \mu \mathrm{l}$ of isopropanol. Samples were washed with $70 \%$ ethanol, resuspended in $80 \%$ formamide-containing marker dyes, and electrophoresed in 5 or $6 \%$ (wt/vol) polyacrylamide gels containing $50 \%$ (wt $/ \mathrm{vol})$ urea (Maxam and Gilbert 1980). For preparation of RNA for S1 mapping, ${ }^{32} \mathrm{P}$ was omitted and UTP was present at $200 \mu \mathrm{M}$. In vitro RNA was isolated as described (Erickson et al. 1987).

\section{S1 nuclease mapping}

S1 nuclease mapping (Berk and Sharp 1977) was performed as described for rpoH mRNA (Erickson et al. 1987) or hrtA mRNA (Lipinska et al. 1988). Samples were electrophoresed on DNA sequencing gels containing either $6 \%($ rpoH $)$ or $4.5 \%(h t r A)$ polyacrylamide and $50 \%$ (wt/vol) urea (Maxam and Gilbert 1980). The method of Salser et al. (1967) was used to isolate in vivo RNA.

\section{Acknowledgments}

We thank B. Lipinska and C. Georgopoulos for sharing their unpublished results and for providing the $h t r A$ plasmid. D. Straus, L. Heisler, and A.K. Schlimgen provided helpful comments on the manuscript. This work was supported by $\mathrm{Na}$ tional Institutes of Health grants GN-36278 and AI-19635 to C.A.G.

\section{References}

Arndt-Jovin, D.J., T.M. Jovin, W. Bahr, A. Frischauf, and M. Marquardt. 1975. Covalent attachment of DNA to agarose. Eur. J. Biochem. 54: 411-418.

Arnosti, D.N. and M.J. Chamberlin. 1989. A secondary sigma factor controls transcription of flagellar genes in $E$. coli. Proc. Natl. Acad. Sci. 86: 830-834.

Berk, A.J. and P.A. Sharp. 1977. Sizing and mapping of early adenovirus mRNAs by gel electrophoresis of S1 nuclease-digested hybrids. Cell 12: 721-732.

Bloom, M., S. Skelly, R. VanBogelen, F. Neidhardt, N. Brot, and H. Weissbach. 1986. In vitro effect of the Escherichia coli heat shock regulatory protein on expression of heat shock genes. I. Bacteriol. 166: 380-384.

Burgess, R.R. and J.J. Jendrisak. 1975. A procedure for the rapid, large-scale purification of Escherichia coli DNA-dependent RNA polymerase involving Polymin $\mathrm{P}$ precipitation and DNA-cellulose chromatography. Biochemistry 14: 46344638.

Buttner, M.J., A.M. Smith, and M.J. Bibb. 1988. At least three different RNA polymerase holoenzymes direct transcription of the agarose gene (dagA) of Streptomyces coelicolor A3(2). Cell 52: 599-607.

Casadaban, M.J. and S.N. Cohen. 1980. Analysis of gene control signals by DNA fusion cloning in Escherichia coli. I. Mol. Biol. 138: 179-207.

Cooper, S. and T. Ruettinger. 1975. A temperature sensitive nonsense mutation affecting the synthesis of a major protein of Escherichia coli K12. Mol. Gen. Genet. 139: 167176.

Cowing, D.W., J.C.A. Bardwell, E.A. Craig, C. Woolford, R. Hendrix, and C. Gross. 1985. Consensus sequence for Escherichia coli heat-shock gene promoters. Proc. Natl. Acad. Sci. 80: $2679-2683$.

Erickson, I.W., V. Vaughn, W.A. Walter, F.C. Neidhardt, and C.A. Gross. 1987. Regulation of the promoters and transcripts of $r p o H$, the Escherichia coli heat shock regulatory gene. Genes Dev. 1: 419-432.

Fuiita, N. and A. Ishihama. 1987. Heat-shock induction of RNA polymerase sigma-32 synthesis in Escherichia coli: Transcriptional control and a multiple promoter system. Mol. Gen. Genet. 210: 10-15.

Givskov, M., L. Olsen, and S. Molin. 1988. Cloning and expression in Escherichia coli of the gene for the extracellular phospholipase Al from Serratia liquefaciens. I. Bacteriol. 170: $5855-5862$.

Gross, C.A., F. Engbaek, T. Flammang, and R. Burgess. 1976. Rapid micromethod for the purification of Escherichia coli ribonucleic acid polymerase and the preparation of bacterial extracts active in ribonucleic acid synthesis. I. Bacteriol. 128: $382-389$.

Grossman, A.D., J.W. Erickson, and C.A. Gross. 1984. The htpR gene product of $E$. coli is sigma factor for heat-shock promoters. Cell 38: 383-390.

Grossman, A.D., R.R. Burgess, W. Walter, and C.A. Gross. 1983. Mutations in the lon gene of E. coli K12 phenotypically suppress a mutation in the sigma subunit of RNA polymerase. Cell 32: 151-159.

Hager, D.A. and R.R. Burgess. 1980. Elution of proteins from sodium dodecyl sulfate-polyacrylamide gels, removal of sodium dodecyl sulfate, and renaturation of enzymatic activity: Results with sigma subunit of Escherichia coli RNA polymerase, wheat germ DNA topoisomerase, and other enzymes. Anal. Biochem. 109: 76-86.

Hawley, D.K. and W.R. McClure. 1983. Compilation and anal- 
ysis of Escherichia coli promoter DNA sequences. Nucleic Acids Res. 11: 2237-2255.

Hayward, R.S. and J.G. Scaife. 1976. Systematic nomenclature for the RNA polymerase genes of prokaryotes. Nature 260: $646-648$.

Helmann, J.D. and M.J. Chamberlin. 1988. Structure and function of bacterial sigma factors. Annu. Rev. Biochem. 57: $839-872$.

Herendeen, S.L., R.A. VanBogelen, and F.C. Neidhardt. 1979 Levels of major proteins of Escherichia coli during growth at different temperatures. J. Bacteriol. 139: 185-194.

Hunt, T.P. and B. Magasanik. 1985. Transcription of $g \ln A$ by purified Escherichia coli components: Core RNA polymerase and the products of $g \ln F, g \ln G$, and $g \ln L$. Proc. Natl. Acad. Sci. 82: 8453-8457.

Joyce, C.M. and N.D.F. Grindley. 1982. Identification of two genes immediately downstream from the polA gene of Escherichia coli. J. Bacteriol. 152: 1211-1219.

Laemmli, U.K. 1970. Cleavage of structural proteins during the assembly of the head of bacteriophage T4. Nature 227: 680685.

Lipinska, B., S. Sharma, and C. Georgopoulos. Sequence analysis of the htrA gene of Escherichia coli: A $\sigma^{32}$-independent mechanism of heat-inducible transcription. Nucleic Acids Res. 16: 10053-10067.

Lipinska, B., O. Fayet, L. Baird, and C. Georgopoulos. 1989. Identification, characterization and mapping of the Escherichia coli htrA gene, whose product is essential for bacterial growth only at elevated temperatures. 1. Bacteriol. 171: $1574-1584$.

Lowe, P.A., D.A. Hager, and R.R. Burgess. 1979. Purification and properties of the sigma subunit of E. coli DNA-dependent RNA polymerase. Biochemistry 18: 1344-1352.

Maxam, A.M. and W. Gilbert. 1980. Sequencing end-labeled DNA with base-specific chemical cleavages. Methods Enzymol. 65: 499-560.

McKenney, K., H. Shimatake, D. Court, U. Schmeissner, and M. Rosenberg. 1981. A system to study promoter and terminator signals recognized by Escherichia coli RNA polymerase. In Gene amplification and analysis 2. (ed. J. Chirikjian and T. Papas|, pp. 383-415. North Holland Press, Amsterdam.

Neidhardt, F.C. and R.A. VanBogelen. 1981. Positive regulatory gene for temperature-controlled proteins in Escherichia coli. Biochem. Biophys. Res. Commun. 100: 894-900.

- 1987. Heat shock response. In Escherichia coli and Salmonella typhimurium: Cellular and molecular biology (ed. F.C. Neidhardt, J.L. Ingraham, K.B. Low, B. Magasanik, M. Schaecter, and H.E. Umbarger), pp. 1334-1345. American Society for Microbiology, Washington, D.C.

Neidhardt, F.C., R.A. VanBogelen, and E.T. Lau. 1982. The high-temperature regulon of Escherichia coli. In Heat shock from bacteria to man. (ed. M.J. Schlesinger, M. Ashburner, and A. Tissieres), pp. 139-145. Cold Spring Harbor Laboratory, Cold Spring Harbor, New York.

1983. Molecular cloning and expression of a gene that controls the high-temperature regulon of Escherichia coli. $J$. Bacteriol. 153: 597-603.

Neidhardt, F.C., R.A. VanBogelen, and V. Vaughn. 1984. Genetics and regulation of heat shock proteins. Annu. Rev. Genet. 18: 295-329.

Ninfa, A.J., D.A. Mullin, G. Ramakrishnan, and A. Newton. 1989. Escherichia coli $\sigma^{54}$ RNA polymerase recognized Caulobacter cresentus flbG and flaN flagellar gene promoters in vitro. I. Bacteriol. 171: 383-391.

Oliver, D. 1985. Protein secretion in Escherichia coli. Annu. Rev. Microbiol. 39: 615-648.
Paek, K.H. and G.C. Walker. 1986. Defect in expression of heat-shock proteins at high temperature in $x$ th $A$ mutants. $I$. Bacteriol. 165: 763-770.

Randall, L.L., S.J.S. Hardy, and J.R. Thom. 1987. Export of protein: A biochemical view. Annu. Rev. Microbiol. 41: 507541 .

Reznikoff, W.S., D.A. Siegele, D.W. Cowing, and C.A. Gross. 1985. The regulation of transcription initiation in bacteria. Annu. Rev. Genet. 19: 355-387.

Salser, W., R.F. Gesteland, and A. Bolle. 1967. In vitro synthesis of bacteriophage lysozyme. Nature 215: 588-591.

Skelly, S., T. Coleman, C.-F. Wu, N. Brot, and H. Weissbach. 1987. Correlation between $32-\mathrm{kDa} \sigma$ factor levels and in vitro expression of Escherichia coli heat shock genes. Proc. Natl. Acad. Sci. 84: 8365-8369.

Strauch, K.L. and J. Beckwith. 1988. An Escherichia coli mutation preventing degradation of abnormal periplasmic proteins. Proc. Natl. Acad. Sci. 85: 1576-1580.

Straus, D.B., W.A. Walter, and C.A. Gross. 1987. The heat shock response of Escherichia coli is regulated by changes in the concentration of $\sigma^{32}$. Nature 329: 348-351.

Tabor, S. and C.C. Richardson. 1987. DNA sequence analysis with a modified bacteriophage T7 DNA polymerase. Proc. Natl. Acad. Sci. 84: 4767-4771.

Tilly, K., J. Erickson, S. Sharma, and C. Georgopoulos. 1986. Heat shock regulatory gene $r p o H$ mRNA level increases after heat shock in Escherichia coli. J. Bacteriol. 168: 11551158.

VanBogelen, R.A., M.A. Acton, and F.C. Neidhardt. 1987a. Induction of the heat shock regulon does not produce thermotolerance in Escherichia coli. Genes Dev. 1: 525-531.

VanBogelen, R.A., P.M. Kelley, and F.C. Neidhardt. 1987b. Differential induction of heat shock, SOS, and oxidative stress regulons and accumulation of nucleotides in Escherichia coli. J. Bacteriol. 169: 26-32.

Wray, W., T. Boulikas, V.P. Wray, and R. Hancock. 1981. Silver staining of proteins in polyacrylamide gels. Anal. Biochem. 118: 197-203.

Yamamori, T. and T. Yura. 1982. Genetic control of heat-shock protein synthesis and its bearing on growth and thermal resistance in Escherichia coli K12. Proc. Natl. Acad. Sci. 79: 860-864.

Yanisch-Perron, C.J. Viera, and J. Messing. 1985. Improved M13 phage cloning vectors and host strains: Nucleotide sequences of the M13mpl8 and pUC19 vectors. Gene 33: $103-119$. 


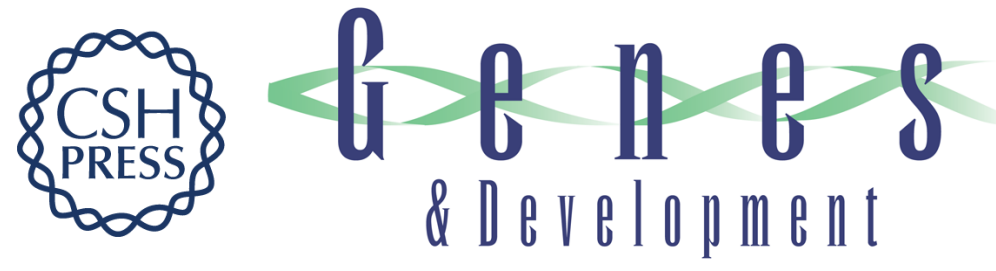

\section{Identification of the sigma E subunit of Escherichia coli RNA polymerase: a second alternate sigma factor involved in high-temperature gene expression.}

J W Erickson and C A Gross

Genes Dev. 1989, 3:

Access the most recent version at doi:10.1101/gad.3.9.1462

References This article cites 45 articles, 19 of which can be accessed free at: http://genesdev.cshlp.org/content/3/9/1462.full.html\#ref-list-1

License

Email Alerting Service

Receive free email alerts when new articles cite this article - sign up in the box at the top right corner of the article or click here.

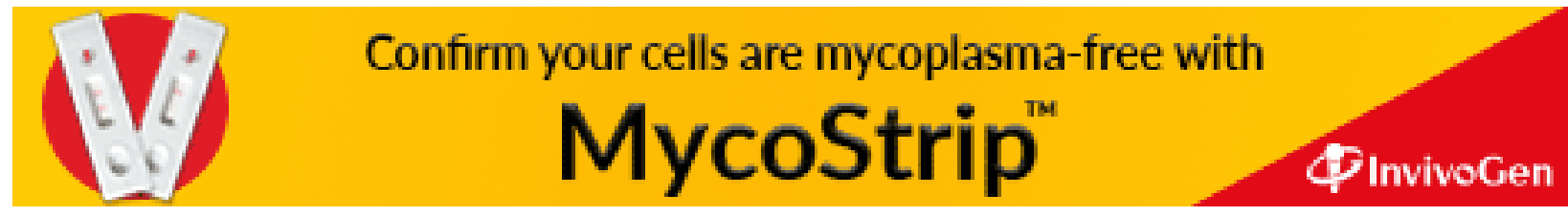

